and how to streamline the review process for student visa applicants so that the United States remains the leading host country for international students. A summit of university presidents hosted by the US secretary of state and US secretary of education, held in January 2005, articulated a strong commitment at the national level, while US higher education institutions continue to develop their own strategies to attract international students.

For the Open Doors 2005 Report on International Educational Exchange or the fall 2005 online survey, see: http://opendoors.iienetwork.org. For the Atlas of Student Mobility project, see: http://atlas.iienetwork.org.

\section{Where Are the International Students Going?}

\section{Geographic Locus}

Most recent reports note shifts in the country of origin of foreign students. Clearly the numbers from Muslim countries are down; from 2002 there was a sharp drop in students from the Middle East, and this past year, the numbers from Indonesia fell off. Lately there is also an apparent decline in students from China.

Surprisingly, in view of the economic trade rhetoric associated with recent reports of foreign student enrollments, there is little commentary on the geographic areas foreign students are inclined to select and reject. But a look at the numbers suggests a shift away from the Northeast toward the Southwest and mountain states. Within each region, there are more complicated patterns. For example, while the Northeast is down, Maryland is steadily up. And while the West is down, Hawaii is up.

\section{Sectoral Shifts}

Another perspective on recent trends is to consider the sectoral choices of foreign students. Using I994 as the base year, most sectors experienced substantial growth in foreign student enrollments through 200I with the exception of the baccalaureate sector that first experienced a sharp drop through 2000 , followed by a slow recovery. For most of the other sectors, 200I was the beginning of a downturn with signs of recovery in 2004. In contrast, for the university sector (including Research I and II and Doctoral I and II), 2004 was the first instance of a substantial downturn in over two decades.

The downturn for the university sector is especially notable as a relatively large proportion of the foreign students in this sector receive graduate assistant and research assistant stipends. Thus, despite the substantial incentives offered by this sector, there has been a decrease in the number of foreign students attracted to the United States to pursue these opportunities. Indeed, the numbers are down even though, according to the Council of Graduate Schools, many graduate schools report they have increased their admissions rates in an attempt to maintain their traditional intake of foreign-born graduate students.

Despite the substantial incentives offered by this
sector, there has been a decrease in the number of
foreign students attracted to the United States to
pursue these opportunities.

Turning to the other sectors, it can be argued that their primary focus is on providing associate-level or undergraduate education for a fee. To learn more about the behavior of the institutions in these sectors, we sampled ro7 institutions in the liberal arts sector, 70 in the specialized sector, and 40 in the associate sector and compiled detailed statistical profiles of each institution from I994 through 2004. The following generalizations are based on our analysis of the respective samples. 
The great majority of the institutions in these other sectors are private institutions. In general, the institutions in these sectors have modest student-teacher ratios (on average II to I), though many staff are part time, especially at those institutions specializing in business and fine arts. While many institutions have sought to improve their quality, some, especially in the associate sector, have experienced financial hardships and hence some quality downgrading. For example, full-time faculty in the associate sector declined 20 percent between 1994 and 200I, and the average admission rate at these institutions exceeded 80 percent by 200I; the average SAT scores of students entering these institutions are comparatively low and have in the 200I-03 period experienced a decline.

Most have modest total enrollments (I,000 to 5,000 students) and some have experienced dramatic ups and downs in

\section{Foreign student enrollments in the baccalaureate sector have been relatively stable.}

overall enrollments. The average enrollment in the associatedegree institutions was 2,554 in I994, but declined to 1,832 in 2003. Average enrollments in the other sectors have been more stable.

Interest in foreign students at these institutions varies and has changed over time. Liberal arts institutions tend to seek a certain representative participation of foreign students to enhance the diversity of their student body. Specialized schools such as business, engineering, and fine arts have sought foreign students as part of their overall strategy to expand enrollments (in 200I foreign students made up approximately 20 percent of the enrollments in these specialized institutions, or nearly four times the average percentage for other institutions in these three sectors). Institutions in the associate-degree sector have sometimes turned to foreign student recruitment to make up for declining domestic enrollments.

Foreign student enrollments in the baccalaureate sector have been relatively stable. There was a slight downturn from I994 to 200I followed by a leveling off. Enrollments in the associate-degree group went sharply down after 200I-io percent from the 200I peak, though still above the I994 levelbefore apparently recovering in 2004 . Within the associate sector, the downturn was less substantial for the upper tier of this sector, only 5 percent. That is, those institutions that only offer associate degrees experienced a much sharper decline (I4 percent) than those offering bachelor's and associate degrees.

Turning to the specialized sector, overall there was a modest increase in foreign student enrollments through $200 \mathrm{I}$ followed by a Io percent decline after 200I. But within this sector there is much variation. All parts, except specialized medicine, have experienced declines since 200I. Some specializations such as business, health, fine arts, and engineering are dramatically down (to their 1994 level or below). The average number of foreign students enrolled in business specialty schools is down nearly 50 percent from its 200 I peak. Specialized engineering and fine arts both declined by about $\mathrm{I} 5$ percent.

\section{A Dual Market for Foreign Students?}

For the university sector, we find there was essential stability in foreign student enrollments until the last two years. But in other sectors under scrutiny here we find a more complicated picture. The liberal arts sector is holding steady, but there have been ups and downs in the associate sector along with declines in several subgroups of the specialized sector.

Whereas in the university sector, private institutions experienced a larger drop in foreign student enrollments than public institutions, for the baccalaureate and associate-degree sectors the public institutions experienced a greater decline. This suggests a "dual" market-for associate and four-year-degree institutions, foreign students tend to be more price sensitive. For graduate studies, foreign students are prestige sensitive. Behind these differences is the reality that a greater proportion of foreign students in graduate studies receive financial aid than do those at the undergraduate level.

\section{GATS: The Way Forward After Hong Kong}

\section{JANE KNIGHT}

Jane Knight is adjunct professor at the Comparative, International, Development Education Centre, Ontario Institute for Studies in Education, University of Toronto, Canada. She is currently working at CENEVAL in Mexico City. E-mail: janeknight@sympatico.ca and jane.knight@ceneval.edu.mx.

The General Agreement on Trade in Services (GATS) nego1 tiations during 2005 were basically in a logjam. The current round of negotiations, known as the Doha Round, was scheduled to end in January 2005 , but there have been major delays and the end date is now set for October 3I, 2006. It is important to realize that the Doha Round includes negotiations on three different aspects of international trade-two that deal with goods and one that focuses on services. The first is "agriculture," with which the most contentious issue is the reduction of domestic support to farmers-primarily by the European Union and the United States. The second is "nonagriculture market access," regarding which the reduction of tariffs is the key stumbling block, and the third is trade in services as enshrined in GATS. The first two issues created the paralysis, but the logjam has been loosened by agreements at 